\title{
Direct Assay to Evaluate Phosphoenolpyruvate Carboxykinase Activity
}

\author{
Bruno S. do Amaral, ${ }^{a}$ Katia Celina S. Correa, ${ }^{a}$ Arlene G. Corrêa, ${ }^{a}$ \\ Dulce H. F. de Souza*,a and Quezia B. Cass ${ }^{\circledR} * a$ \\ ${ }^{a}$ Departamento de Química, Universidade Federal de São Carlos, \\ Rod. Washington Luís, km 235, 13565-905 São Carlos-SP, Brazil
}

\begin{abstract}
Phosphoenolpyruvate carboxykinase (PEPCK) is a ubiquitous enzyme found in all known groups of organisms, acting in the reversible conversion of oxaloacetate (OAA) to phosphoenolpyruvate (PEP) in the presence of divalent metal ion, and dependent of adenosine 5'-triphosphate (ATP) or guanosine-5' -triphosphate (GTP). PEPCK is an important enzyme in the metabolism of some organisms, such as Trypanosoma cruzi, being suggested as a potential drug target to treat Chagas' disease. Its catalytic activity is, classically, measured by coupled assays. Herein, a direct assay by liquid chromatography-tandem mass spectrometry (LC-MS/MS) capable of quantifying PEP, in co-elution with OAA by the differentiation obtained by the mass spectra, is reported. The developed assay was used throughout the purification protocol in order to measure the activity of PEPCK of T. cruzi, which was expressed in Escherichia coli. The purified enzyme was kinetically characterized by the developed method with Michaelis-Menten constant $\left(K_{\text {Mapp }}\right)$ values of $96 \pm 4$ and $275 \pm 18 \mu \mathrm{mol} \mathrm{L}^{-1}$ to OAA and ATP as substrates, respectively. The developed assay was also used for ligand screening and proved to be able to identify very low inhibitions for small molecules $\left(50 \mu \mathrm{mol} \mathrm{L} \mathrm{L}^{-1}\right)$.
\end{abstract}

Keywords: PEPCK activity assay, PEPCK purification, LC-MS/MS

\section{Introduction}

Phosphoenolpyruvate carboxykinase (PEPCK) is a widely distributed enzyme present in most organisms. ${ }^{1}$ Its catalytic activity is related to reversible decarboxylation and phosphorylation of oxaloacetate (OAA) to yield phosphoenolpyruvate (PEP) and carbon dioxide, in the presence of a nucleotide (adenosine 5'-triphosphate (ATP) or guanosine-5' -triphosphate (GTP)) and has an absolute requirement for divalent metal ions as cofactor.

Based on the nucleotide specificity, PEPCKs can be divided into two families, whereby ATP-dependent (EC 4.1.1.49) are found in bacteria, yeasts, higher plants and trypanosomatids; and GTP-dependent (EC 4.1.1.32), in mollusks, insects, fungi and vertebrate animals. ${ }^{1-3}$ Different levels of sequence homology are observed among PEPCKs from the same family, but a low identity (18-20\%) is verified between PEPCKs from different families. No similarity is, however, observed at the nucleotide binding sites between the families, justifying the specific dependence of one nucleotide or the other. ${ }^{3,4}$

\footnotetext{
*e-mail: qcass@ufscar.br; dulce@ufscar.br
}

In vertebrates, PEPCK is involved in glycogenesis, while in Trypanosoma cruzi, the causative agent of Chagas' disease, other trypanosomatids and Leishmania are involved in glucose catabolism. ${ }^{5,6}$ The aerobic fermentation of glucose, in T. cruzi, leads to the production of reduced catabolites: succinate and L-alanine as major products linked to the re-oxidation of glycolytic NADH (reduced nicotinamide adenine dinucleotide). The production of succinate depends on $\mathrm{CO}_{2}$ fixation, which is mediated by PEPCK by the production of OAA from PEP in the glycosome. Subsequently, OAA can be reduced to malate (by malate dehydrogenase), which enters the Krebs cycle in the mitochondria, producing succinate as the end product of catabolism. At the same time, glycosomal malate following entry into the cytosol can participate of the glutamate dehydrogenase pathway, leading to the production of L-alanine. ${ }^{7,8}$

T. cruzi is able to catabolize L-proline, as well as other amino acids. ${ }^{8}$ In the absence of carbohydrates, the acetylCoA, oxaloacetate or malate would accumulate unless they re-enter in the Krebs cycle, respectively, as PEP or pyruvate. PEP, produced by PEPCK through oxaloacetate decarboxylation, could also be used for gluconeogenesis. 
Moreover, it has been reported, based on the properties of a purified enzyme under physiological conditions, that this is the reaction favored by PEPCK, ${ }^{7}$ and the catabolism of proline with conversion to pyruvate, alanine, citrate and isocitrate was blocked in presence of 3-mercaptopicolinic acid (3MP), which is known as a PEPCK inhibitor. ${ }^{9}$ Therefore, PEPCK is a key enzyme described in all cycle life of $T$. cruzi in the use of carbohydrates and amino acids as energy source, and due to the significant differences between human and T. cruzi PEPCK, the latter has been considered a potential target in drug development research for Chagas' disease. ${ }^{3,6,10}$

The PEPCK catalytic activity tends to be measured by indirect assays involving the oxidation of NADH to $\mathrm{NAD}^{+}$ (Scheme 1). The first developed assay was the one depicted in Scheme $1 \mathrm{a},{ }^{11}$ in which catalytic activity of PEPCK was measured by the incorporation of ${ }^{14} \mathrm{CO}_{2}$ in OAA. In 1954, a coupled assay was developed, ${ }^{12}$ and the produced OAA by the PEPCK is converted to malate by malate dehydrogenase (MDH), with consequent oxidation of NADH to $\mathrm{NAD}^{+}$ (Scheme 1b). As a complementary way of measuring the catalytic activity, the assay $1 \mathrm{~b}$ is often used in conjunction with isotopically C-labeled (Scheme 1a frame). The assays for monitoring PEP formation were introduced much later, initially by monitoring inorganic phosphate. ${ }^{13}$ Then, a coupled spectrophotometric assay was reported, this time using pyruvate kinase (PK) and lactate dehydrogenase (LDH) with oxidation of NADH (Scheme 1c). ${ }^{14,15}$

The methods presented in Scheme 1 were all developed between the 1950s and 1960s, but they are still in use for measuring the activity of PEPCK from different sources ${ }^{16-23}$ with few or no modification. The two most used
(Schemes 1b and 1c) rely on NADH-dependent enzymes in which the PEPCK activity is indirectly monitored by the absorbance decrease at $340 \mathrm{~nm}$ as a result of NADH depletion. To make things murkier, NADH has been reported as an inhibitor of Escherichia coli PEPCK, with maximal inhibition of $30 \%$ at $0.5 \mathrm{mmol} \mathrm{L}{ }^{-1},{ }^{24,25}$ which may impact the assay results. Moreover, coupled assays require complete compatibility in the reaction conditions for the enzymes in use making hard to achieve the optimum conditions needed for the catalysis. Usually, a large number of measurements is necessary. ${ }^{26,27}$

Duff and Snell ${ }^{28}$ called attention to their results obtained from a comparative study in which the activity of three crude extracts of PEPCK from different rat muscles was determined by four different coupled assays. A great incongruence was observed among the methods. Two spectrophotometric assays with MDH gave apparent PEPCK activities at least 10 times greater than when obtained by the ${ }^{14} \mathrm{CO}_{2}$-incorporation method. On the other hand, the production of PEP as measured by PK/LDH approach showed negligible activity. The authors also pointed out that $\mathrm{PK}$ activity was slightly inhibited by $\mathrm{Na}^{+}$and stimulated by $\mathrm{K}^{+}, \mathrm{Mg}^{2+}$ and $\mathrm{NH}_{4}^{+}$. These results elegantly disclose the limitation of coupled assays in which any interference in the activity of a given enzyme may generate unreliable results. In spite of this, the reported kinetic parameters and activity assays for native PEPCK of T. cruzi (isolated from epimastigote form of the parasite) have been measured using coupled assays. ${ }^{9,29-32}$

Recombinant PEPCK from T. cruzi (TcPEPCK) had its 3D structure determined by X-ray crystallography in 2001 by Trapani et $a l .{ }^{3}$ as a homodimer, with two active sites far (a)<smiles>C=C(O[PH]([O-])([O-])O)C(=O)O</smiles>

(b)<smiles>C=C(OP(=O)([O-])[O-])C(=O)O</smiles>
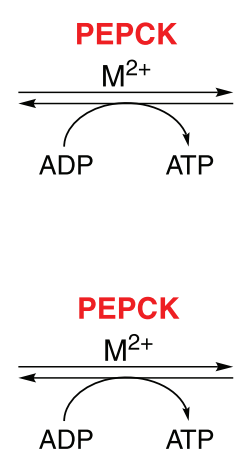

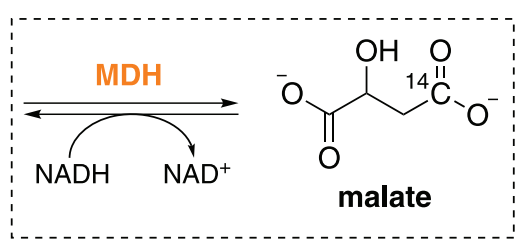

OAA<smiles>COC(=O)CC(=O)C(=O)O</smiles>

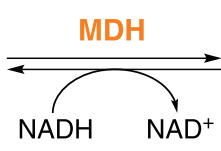<smiles>O=C([O-])CC(O)C(=O)O</smiles>

(c)

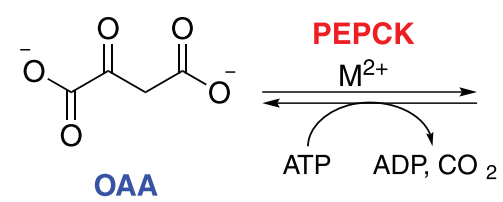<smiles>C=C(OP(=O)([O-])[O-])C(=O)[O-]</smiles>

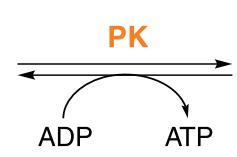

PEP<smiles>CC(=O)C(=O)[O-]</smiles>

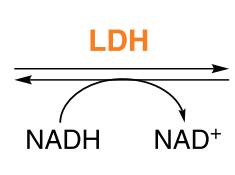

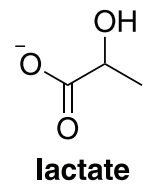

Scheme 1. Classical approaches for measuring the catalytic activity of PEPCK. 
apart from each other and with independent access for the substrates. For that, recombinant PEPCK was expressed in E. coli and purified, but the protocol has not been published.

To overcome the lack of published purification protocols and the disadvantages of the spectrophotometric or labeled assays, herein a direct assay capable of quantifying PEP by liquid chromatography-tandem mass spectrometry (LC-MS/MS) is reported. To meet this end, the TcPEPCK was expressed as an active enzyme in E. coli and purified. The activity of the enzyme throughout the purification steps and biochemical characterization, as well as for the inhibition screening assay, were monitored by the LC-MS/MS method.

\section{Experimental}

\section{Materials}

Ammonium acetate HPLC grade, 4-(2-hydroxyethyl) piperazine-1-ethanesulfonic acid (HEPES), phosphoenolpyruvate monopotassium salt (PEP), oxaloacetic acid (OAA), ATP, manganese chloride monohydrate, dithiothreitol (DTT), ethylenediamine tetraacetic acid (EDTA) were purchased from Sigma-Aldrich (St. Louis, USA). Methanol HPLC grade purchased from J. T. Baker (Philipsburg, USA). The water used for all experiments and mobile phases was ultrapure. The chromatographic analytical column was a $\mathrm{C}_{18}(2)$ Luna $^{\circledR}(3.0 \times 0.20 \mathrm{~cm}, 3 \mu \mathrm{m}$, Phenomenex, Torrance, CA, USA).

Hypoxanthine $\geq 99 \%$, xanthine $\geq 99.5 \%$, ofloxacin $\geq 99 \%$, albendazole $\geq 98 \%$, iodoacetamide $\geq 99 \%$, quinolinic acid $99 \%$ and NADH $\geq 97 \%$ were purchased from Sigma-Aldrich (Saint Louis, MO, USA). Aciclovir (lot: M24136-1) was donated by EMS (Hortolândia-SP, Brazil). 2-Mercaptobenzimidazole 98\%, 2-mercaptobenzoxazole 99\%, 6-mercaptopurine $\geq 99.5 \%$, 2-mercapto-5-methylbenzimidazole $99 \%$ and resorcinol sulfide $98 \%$ were purchased from Acros Organics (Geel, Belgium). The coumarins LSPN214 and LSPN234 were prepared as previously described, ${ }^{33}$ and, for coumarins LSPN223, LSPN224 and LSPN272, see Supplementary Information (SI) section. Gemifloxacin (lot: QUB10006) was donated by Ache (São Paulo-SP, Brazil). Moxifloxacin (lot: M201400) was donated by Vita Nova Institute (Hortolândia-SP, Brazil).

All other chemicals used are analytical grade purchased from Sigma-Aldrich.

\section{Instruments}

TcPEPCK purification was carried out using an ÄKTA fast protein liquid chromatography (FPLC) system from
GE Healthcare (Little Chalfont, UK) composed by an UV UPC 900 detector, a P-920 pump, a FRAC-920 fraction collector and the chromatograms were registered by Unicorn software.

The TcPEPCK activity was monitored using LC-MS/MS. The LC system (Shimadzu, Kyoto, Japan) consisted of two LC-20AD pumps, a SIL 20A autosampler with a $50 \mu \mathrm{L}$ loop, a DGU-20A5 degasser, a CTO-20A column oven and a CBM-20A interface. All LC analyses were carried out at $30{ }^{\circ} \mathrm{C}$. The LC system was coupled to an Esquire 6000 IT mass spectrometer (Bruker Daltonics, Bremen, Germany) equipped with an electrospray ionization (ESI) source. Data acquisition was carried out using Bruker Daltonics data analysis software.

\section{TCPEPCK expression}

The TcPEPCK gene was cloned into the expression vector pANEX, resulting in the plasmid pANEXTcPEPCK, ${ }^{3,34}$ which was used to transform E. coli BL21(DE3)pT-GroE strain. A $500 \mathrm{~mL}$ of Luria-Bertani medium supplemented with ampicillin $\left(100 \mu \mathrm{g} \mathrm{mL}^{-1}\right)$ and chloramphenicol $\left(34 \mu \mathrm{g} \mathrm{mL}^{-1}\right)$ was inoculated with $1 \mathrm{~mL}$ of an overnight culture of the $E$. coli BL21(DE3)pT-GroE strain containing the recombinant pANEX-TcPEPCK plasmid. The culture was grown at $37{ }^{\circ} \mathrm{C}$ and $250 \mathrm{rpm}$ to a cell density of $\mathrm{A}_{600 \mathrm{~nm}}$ of 0.6-0.8, and the expression of protein was induced for $5 \mathrm{~h}$ at $37{ }^{\circ} \mathrm{C}$ and $250 \mathrm{rpm}$ by adding IPTG (isopropyl $\beta$ - $D$-1-thiogalactopyranoside) to a final concentration of $1 \mathrm{mmol} \mathrm{L}^{-1}$. The culture (aliquots of $125 \mathrm{~mL}$ ) was then centrifuged at $9,000 \times \mathrm{g}$ for $10 \mathrm{~min}$ at $4{ }^{\circ} \mathrm{C}$. The pellets were then stored at $-80{ }^{\circ} \mathrm{C}$ until use.

\section{TcPEPCK purification}

\section{Cells lysis}

The pellet was resuspended in $10 \mathrm{~mL}$ of buffer I (50 mmol L $\mathrm{m}^{-1} \mathrm{HEPES} \mathrm{pH} \mathrm{6.8,} \mathrm{containing} 2 \mathrm{mmol} \mathrm{L}^{-1}$ EDTA

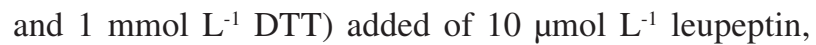
$1 \mu \mathrm{mol} \mathrm{L}-1$ pepstatin and $1 \mathrm{mmol} \mathrm{L}-1$ phenylmethanesulfonyl fluoride (PMSF). Cells were lysed by sonication $(24 \%$ amplitude, $15 \mathrm{~s}$ on, $30 \mathrm{~s}$ off, for $4 \mathrm{~min}$ ) (Sonic Dismembrator, Model 500, Fisher Scientific, Pittsburgh, USA) on ice bath and the suspension was centrifuged at $10,000 \times \mathrm{g}$ for 30 min at $4{ }^{\circ} \mathrm{C}$.

\section{Salting out}

The supernatant (here called crude extract), prior to the chromatography steps, was precipitated with $\left(\mathrm{NH}_{4}\right)_{2} \mathrm{SO}_{4}$. The salt was added to the enzyme extract up to $40 \%$ of saturation, and after $1.5 \mathrm{~h}$ at $4{ }^{\circ} \mathrm{C}$, the insoluble contents were then 
removed by centrifugation $\left(3,000 \times \mathrm{g}\right.$ for $10 \mathrm{~min}$ at $\left.4{ }^{\circ} \mathrm{C}\right)$. The supernatant was dialyzed overnight against buffer I.

\section{Anion exchange chromatography}

$5 \mathrm{~mL}$ of the dialyzed solution were applied onto a QFF-Sepharose ${ }^{\mathrm{TM}}$ column (column volume of $1 \mathrm{~mL}$, GE Healthcare, Little Chalfont, UK) pre-equilibrated with buffer I in an ÄKTA-FPLC ${ }^{\text {TM }}$ system at a flow rate of $0.5 \mathrm{~mL} \mathrm{~min}^{-1}$; fractions of $1 \mathrm{~mL}$ were collected. TcPEPCK was eluted in the ten first fractions. Aiming to high purity, fractions 2 to 7 were pooled (named here as TcPEPCK-I), while fraction 8 (named as TcPEPCK-II) was not combined with any other fraction. For eluting proteins with high retention, $5 \mathrm{~mL}$ of buffer I added of $1 \mathrm{~mol} \mathrm{~L}^{-1} \mathrm{NaCl}$ were used. For storage, the fractions of $T c$ PEPCK-I and $T c$ PEPCK-II were kept in buffer I at $-20^{\circ} \mathrm{C}$.

\section{Affinity chromatography}

$3 \mathrm{~mL}$ of TCPEPCK-I sample were diluted in $7 \mathrm{~mL}$ of buffer II (20 mmol L-1 HEPES pH 7.5, containing $0.1 \mathrm{mmol} \mathrm{L}^{-1}$ EDTA, $0.5 \mathrm{mmol} \mathrm{L}^{-1} \mathrm{DTT}, 2 \mathrm{mmol} \mathrm{L} \mathrm{MnCl}_{2}$, $1 \mathrm{mmol} \mathrm{L}^{-1} \mathrm{MgCl}_{2}$ and $100 \mathrm{mmol} \mathrm{L}^{-1} \mathrm{KCl}$ ) and applied onto the adenosine $5^{\prime}$-triphosphate (ATP)-agarose column (column volume of $1 \mathrm{~mL}$, Sigma-Aldrich, St. Louis, USA), which was pre-equilibrated with the same buffer in the ÄKTA-FPLC ${ }^{\text {TM }}$ system. After eluting the proteins that had no affinity to the column with $10 \mathrm{~mL}$ of buffer II at a flow rate of $0.3 \mathrm{~mL} \mathrm{~min}^{-1}, T c$ PEPCK-III was obtained by elution with $3 \mathrm{~mL}$ of buffer III (200 mmol L-1 phosphate buffer pH 6.8, containing 4 mmol L$^{-1}$ EDTA). TcPEPCK-III was stored in buffer III at $-20^{\circ} \mathrm{C}$, and, for the activity assay, the sample was diluted with buffer II.

All purification steps were followed LC-MS/MS enzymatic activity assays of the eluted fractions and by sodium dodecyl sulfatepolyacrylamide gel electrophoresis (SDS-PAGE), ${ }^{35}$ using two different molecular weight markers: unstained protein molecular weight $(116.0,66.2$, 45.0, 35.0, 25.0, 18.4 and 14.4 kDa, Thermo Scientific, Waltham, USA) and spectra multicolor broad range protein $(260,140,95,72,52,42,34,26,17$ and $10 \mathrm{kDa}$, Thermo Scientific). The enzyme concentrations were determined using Coomassie Brilliant Blue G250 according to the method of Bradford ${ }^{36}$ using the Bio-Rad protein assay kit (Bio-Rad Laboratories, Richmond, CA, USA) and bovine serum albumin as standard.

\section{PEPCK activity LC-MS/MS assay}

PEPCK activity was monitored by decarboxylation reaction of OAA. Reactions were carried out with $200 \mu \mathrm{mol} \mathrm{L}{ }^{-1}$ OAA, $240 \mu \mathrm{mol} \mathrm{L}{ }^{-1}$ ATP, $10 \mu \mathrm{L}$ of the purified enzymatic fraction and the final volume adjusted to $100 \mu \mathrm{L}$ with buffer $\mathrm{A}\left(50 \mathrm{mmol} \mathrm{\textrm {L } ^ { - 1 }}\right.$ ammonium acetate buffer $\mathrm{pH} 9.00$, containing $1 \mathrm{mmol} \mathrm{L}^{-1}$ DTT and $1 \mathrm{mmol} \mathrm{L}^{-1}$ $\mathrm{MnCl}_{2}$ ). Reaction time was evaluated at 2.5, 5.0, 7.5, 10, 15, 30 and $60 \mathrm{~min}$, in which the PEP formation was linear with time. A reaction time of 10 min was selected since the product concentration sufficed quantification. Thus, the reaction mixture was incubated at $36{ }^{\circ} \mathrm{C}$ for $10 \mathrm{~min}$, and stopped by the addition of $100 \mu \mathrm{L}$ of methanol $(\mathrm{MeOH})$ followed by centrifugation at $9,300 \times \mathrm{g}, 10 \mathrm{~min}$ and $4{ }^{\circ} \mathrm{C}$.

For analysis, the supernatant $(10 \mu \mathrm{L})$ was injected into the LC-MS/MS. The chromatographic conditions were: $\mathrm{C}_{18}(2)$ Luna ${ }^{\circledR}(5.0 \times 0.20 \mathrm{~cm}, 3 \mu \mathrm{m}$, Torrance, USA) column in an isocratic elution at $0.15 \mathrm{~mL} \mathrm{~min}^{-1}$ with $\mathrm{MeOH}$-ammonium acetate $\left(\mathrm{pH} 8.50,15 \mathrm{mmol} \mathrm{L}^{-1}\right)$ 1:1 (v/v); with ESI source in the following conditions: $2877 \mathrm{~V}$ for the capillary voltage, $15 \mathrm{~V}$ for the skimmer, 30.0 bar for the nebulizer pressure $\left(\mathrm{N}_{2}\right), 8.0 \mathrm{~L} \mathrm{~min}^{-1}$ and $325{ }^{\circ} \mathrm{C}$ for the dry gas flow rate and temperature $\left(\mathrm{N}_{2}\right)$. The decarboxylation product of OAA, $\operatorname{PEP}\left([\mathrm{M}-\mathrm{H}]^{-} \mathrm{m} / \mathrm{z} 167\right)$, was analyzed in negative ion mode $\left(\mathrm{ESI}^{-}\right)$, while multiple reaction-monitoring (MRM) was carried out for acquisition. The fragment ion $\left[\mathrm{PO}_{3}\right]^{-} \mathrm{m} / \mathrm{z}, 79$ was used for quantification and $[\mathrm{M}-\mathrm{H}-\mathrm{CO}]^{-} \mathrm{m} / z, 139$ for confirmation. External calibration curves $\left(5-200 \mu \mathrm{mol} \mathrm{L}^{-1}\right)$ were constructed to quantify the amount of PEP produced, maintaining $100 \mu \mathrm{mol} \mathrm{L}{ }^{-1} \mathrm{OAA}$ constant at all concentration levels of the curves.

Blank samples were prepared under the same described conditions but without addition of ATP. One unit (U) of $T c$ PEPCK activity was defined as the amount of enzyme that released $1 \mu \mathrm{mol}$ of PEP per min under standard assay conditions.

\section{Method qualification}

Method qualification was accomplished in accordance with accepted criteria ${ }^{37}$ (SI section).

Linearity was evaluated using external calibration curves of PEP. Intra- and inter-batch precisions were determined by analysis of three quality controls (QC) samples. Accuracy was evaluated by back-calculation and expressed as the percentage of deviation between the amount found and the amount added at the three concentrations examined. Matrix effects were evaluated by infusion of PEP prepared with only buffer A and mixture of OAA, ATP, ADP and TcPEPCK.

\section{Effect of temperature and $\mathrm{pH}$ in the TCPEPCK activity}

TcPEPCK-II was used to evaluate the $\mathrm{pH}$ and temperature effect on the enzyme activity. To meet this end, buffer A was used with variations in the $\mathrm{pH}$ range of 
8.2 to 10.0 (limited by ammonium acetate used as volatile buffer, strictly necessary due to the coupling with MS). To evaluate the temperature influence on enzyme activity, assays were carried out at $\mathrm{pH} 9.0$ of buffer A at different incubation temperatures $\left(19.9\right.$ to $40.9^{\circ} \mathrm{C}$ ).

\section{TcPEPCK kinetic characterization}

Apparent kinetic constant (Michaelis-Menten constant, $K_{\text {Mapp }}$ ) was obtained independently for both substrates OAA and ATP by varying substrate concentration while measuring PEP formation. For that, $1.12 \mathrm{U}$ of $T c$ PEPCK-II was used, and the concentration of the substrate under

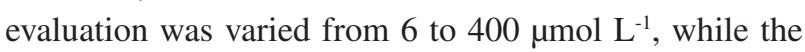
other substrate was maintained at $500 \mu \mathrm{mol} \mathrm{L}^{-1}$. The final volume was adjusted to $100 \mu \mathrm{L}$ with buffer $\mathrm{A}$ at $\mathrm{pH} 9.0$ and the reaction mixture was incubated at $36^{\circ} \mathrm{C}$ for $10 \mathrm{~min}$, and stopped by the addition of $100 \mu \mathrm{L}$ of methanol $(\mathrm{MeOH})$ followed by centrifugation at $9,300 \times \mathrm{g}, 10 \mathrm{~min}$ and $4{ }^{\circ} \mathrm{C}$. The supernatant $(10 \mu \mathrm{L})$ was analyzed by LC-MS/MS.

The experiments were performed in triplicate and the $K_{\text {Mapp }}$ values, values for both substrates were estimated using GraphPad Prism 5.0 software $^{38}$ by nonlinear regression analysis.

\section{Ligand screening}

Activity of $T c$ PEPCK in the presence of different compounds was monitored by decarboxylation reaction. Reactions were carried out with $150 \mu \mathrm{mol} \mathrm{L}^{-1} \mathrm{OAA}$, $500 \mu \mathrm{mol} \mathrm{L}^{-1} \mathrm{ATP}, 50 \mu \mathrm{mol} \mathrm{L}^{-1}$ of the compounds under trial and $1.12 \mathrm{U}$ of $T c$ PEPCK-II. The final volume was adjusted to $100 \mu \mathrm{L}$ with buffer $\mathrm{A}$. The reactions were incubated at $36{ }^{\circ} \mathrm{C}$ for $10 \mathrm{~min}$, stopped by the addition of $100 \mu \mathrm{L}$ of methanol $(\mathrm{MeOH})$ followed by centrifugation at $9,300 \times \mathrm{g}$,
$10 \mathrm{~min}$ and $4{ }^{\circ} \mathrm{C}$. The supernatants $(10 \mu \mathrm{L})$ were analyzed by LC-MS/MS.

All compounds were dissolved in DMSO/acetone 1:1 $(\mathrm{v} / \mathrm{v})$ at appropriated concentration in which the organic solvent volume was $2 \% \mathrm{v} / \mathrm{v}$ in the reaction mixture. The activity of $T c$ PEPCK was not affected by this concentration of organic solvent.

Negative controls were prepared under herein described conditions but without addition of ATP. Positive controls were prepared as the activity assay samples.

For calculating percentage of inhibition, refer to the equations given in the SI section, as well as for the procedures of sample preparation to evaluate the influence of each screened compound in PEP ionization.

\section{Results and Discussion}

\section{PEPCK activity LC-MS/MS assay}

As presented, there are several indirect methods described in the literature for measuring the activity of PEPCK. These coupled methods have several drawbacks. Herein, a direct method for quantification of PEP by LC-MS/MS is described which is suitable for following the purification process, as well as, for kinetic characterization of the enzyme in solution and for ligand screening.

The difficulty related to the chromatographic separation of PEPCK's substrates and products are their high hydrophilicity and poor retention under reverse-phase elution mode that leads to co-elution or low peak resolution. Separation may be achieved by ion-pair chromatography, but PEPCK activity reaction buffers cause peak tailing. Nevertheless, since MS is able to distinguish compounds based on its molecular ion, the chromatographic conditions can be sacrificed ${ }^{39}$ (Figure 1).

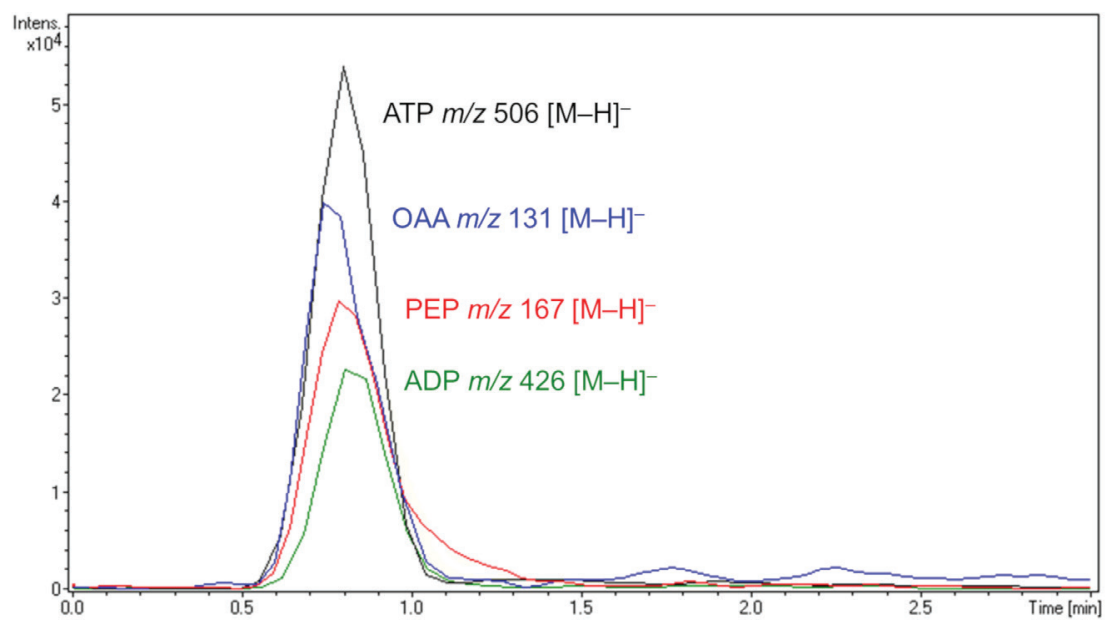

Figure 1. Typical LC-MS chromatograms using the MRM mode: Luna ${ }^{\circledR} \mathrm{C} 18(2)$ column $(30.0 \times 2.00 \mathrm{~mm}, 3 \mu \mathrm{m})$ with ammonium acetate buffer $\left(15 \mathrm{mmol} \mathrm{L}{ }^{-1}\right.$, $\mathrm{pH}$ 8.5)/MeOH 1:1 v/v as mobile phase. 
Table 1. Recovery of activity of fractions after purification of $T c$ PEPCK

\begin{tabular}{lcccc}
\hline Sample & Total activity / $\left(\mathrm{U} \mathrm{mL}^{-1}\right)$ & Protein concentration / $\left(\mathrm{mg} \mathrm{mL}^{-1}\right)$ & Specific activity / $\left(\mathrm{U} \mathrm{mg}^{-1}\right)$ & Purification fold \\
\hline$\left(\mathrm{NH}_{4}\right)_{2} \mathrm{SO}_{4}$ & 167.9 & 2.20 & 76.3 & 1.0 \\
$T c$ PEPCK-I & 289.7 & 0.490 & 591.3 & 7.7 \\
$T c$ PEPCK-II & 112.0 & 0.130 & 860.7 & 11.3 \\
$T c$ PEPCK-III & 25.0 & 0.0198 & 1265.5 & 16.6 \\
\hline
\end{tabular}

Optimum temperature and $\mathrm{pH}$ of the TcPEPCK.

\section{TCPEPCK purification}

After qualifying the developed LC-MS/MS method, a protocol for $T c$ PEPCK purification was developed. The crude extract was precipitated with $\left(\mathrm{NH}_{4}\right)_{2} \mathrm{SO}_{4}$ followed by two chromatographic steps previously to analysis by SDS-PAGE (Figure 2). PEPCK from E. coli was found at the purification step and properly removed by elution with $\mathrm{NaCl}$ at the anion exchange chromatographic step. The differences in retention times of both enzymes allowed the isolation of $T c$ PEPCK free from the E. coli one. While specific activity values for native PEPCK from $T$. cruzi are reported in the range $5.3^{30}$ to $6.25^{32} \mathrm{U} \mathrm{mg}^{-1}$, our results for the recombinant enzyme showed higher activity (Table 1).

In spite of the high specific activity of TcPEPCK-III fraction, dialysis was necessary for its characterizations. The reason is that while the purification (affinity column) was carried out using phosphate buffer, the catalytic reaction does not preclude the use of the cofactor $\mathrm{Mn}^{2+}$, which precipitates with phosphate. Several dialysis conditions were evaluated with different membranes and/or exchange concentrators; in all attempts, the TcPEPCK-III lost partial or total activity. TcPEPCK-III can find its use in other applications, nonetheless. Thus, we thought important to describe the affinity procedure to its obtainment.

Biochemical characterizations were carried out $(\mathrm{n}=3)$ with $T c$ PEPCK-II fraction using the method developed. The enzyme showed high activity in the $\mathrm{pH}$ range of 8.8

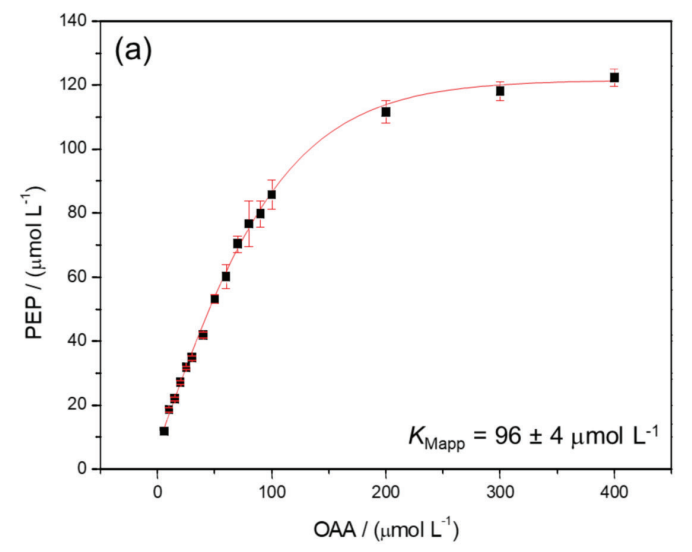

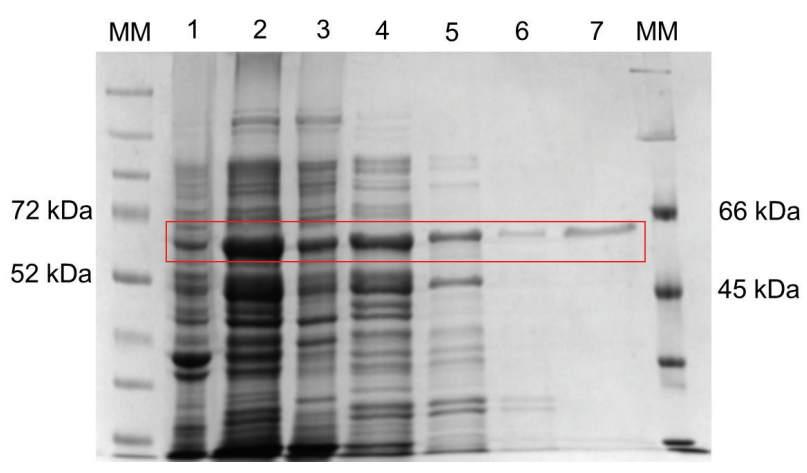

Figure 2. SDS-PAGE analysis of the TcPEPCK purification process. MM, molecular weight markers; culture cells after lysis, pellet (line 1) and supernatant (line 2); precipitation with ammonium sulfate, pellet (line 3) and supernatant (line 4); samples with enzymatic activity eluted of the QFF column (TcPEPCK-I, line 5 and TcPEPCK-II, line 6), sample eluted of the ATP-agarose column (TcPEPCK-III, line 7).

to 10 , with maximum value at $\mathrm{pH} 9.0$. The enzyme was evaluated at different temperature values and showed maximum activity at $36^{\circ} \mathrm{C}$, with a high decrease in activity below $30^{\circ} \mathrm{C}$.

\section{Kinetic characterization of TCPEPCK-II}

Kinetic parameters $K_{\text {Mapp }}$ and $\mathrm{V}_{\text {maxapp }}$ (maximum velocity of enzyme activity) were determined for TcPEPCK-II for both substrates under optimal conditions of $\mathrm{pH}$ and temperature ( $\mathrm{pH} 9.0$ and at $36{ }^{\circ} \mathrm{C}$ ), and the curves are presented in Figure 3.

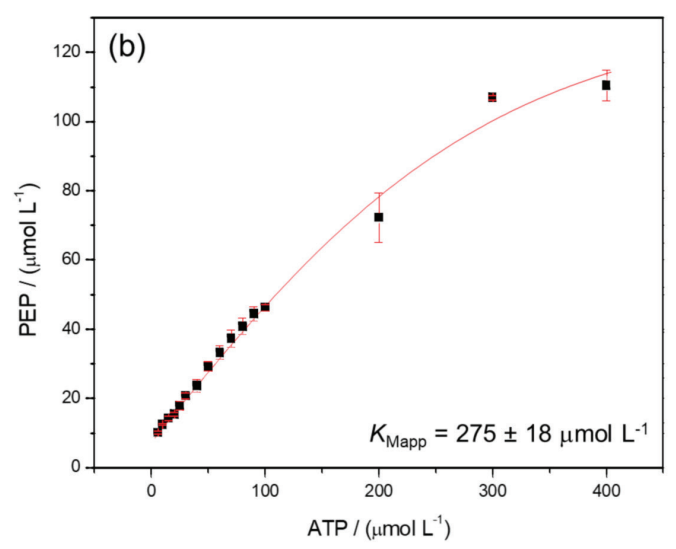

Figure 3. Kinetic curves for (a) OAA and (b) ATP, as substrates of TcPEPCK-II. 
TcPEPCK-II showed a Michaelian kinetic behavior with $K_{\text {Mapp }}$ constant value of $96 \pm 4 \mu \mathrm{mol} \mathrm{L}^{-1}$ to OAA, while the kinetic curve for ATP did not reach the plateau. A biphasic kinetics for ATP in PEPCK from T. cruzi has been, however, reported by Urbina ${ }^{30}$ and, the herein reported $K_{\text {Mapp }}$ value is of $275 \pm 18 \mu \mathrm{mol} \mathrm{L}^{-1}$ for ATP as substrates. The $K_{\text {Mapp }}$ values obtained are higher than those described in the literature for native $T c$ PEPCK. ${ }^{30,32}$ In our own described method, low concentration of $\mathrm{Mn}^{2+}$ cofactor $\left(1 \mathrm{mmol} \mathrm{L}^{-1}\right)$ was employed and, in general, $\geq 3 \mathrm{mmol} \mathrm{L}^{-1}$ of $\mathrm{Mn}^{2+}$ or a combination of $\mathrm{Mn}^{2+} / \mathrm{Mg}^{2+}$ is used. ${ }^{16-19,22,30-32,40}$ In previous experiments, we found that $\mathrm{Mg}^{2+}$ does not influence the activity when compared to $\mathrm{Mn}^{2+}$; thus, $\mathrm{Mg}^{2+}$ was not added. The selection of lower $\mathrm{Mn}^{2+}$ concentration is also justified since at higher concentrations it interferes with the PEP ionization at the MS.

\section{Ligands screening}

The great advantage of the herein reported LC-MS/MS method is that the influence of a trial compound is directly measured by PEP quantification. Besides, the use of MS includes excellent signal to background ratio, assay precision, reproducibility and reduced reagent costs. The most important feature is, however, that it eliminates false readouts that often occur with the use of other assays. ${ }^{41-44}$

$3 \mathrm{MP}$ is the only compound hitherto characterized as ligand to TcPEPCK; it has been reported as a noncompetitive inhibitor. ${ }^{9}$ Thus, in order to search for ligands of this enzyme, a series of small molecules (Figure 4) were selected. The selection was inspired on inhibitors of PEPCK from other organisms. ${ }^{24,32,45-48}$ The

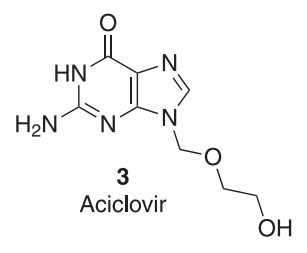

$\overbrace{\mathrm{H}}^{\mathrm{N}} \mathrm{SH}$

$$
7
$$

2-Mercapto-5-methyl benzimidazole<smiles>Sc1nc2ccccc2[nH]1</smiles>

4

2-Mercapto benzimidazole

2-Mercaptobenzoxazole

6 6-Mercaptopurine<smiles>Oc1ccc(Sc2ccc(O)cc2O)c(O)c1</smiles>

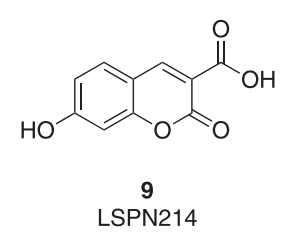<smiles>CCOC(=O)c1cc2ccc(OCCN3CCCCC3)cc2oc1=O</smiles><smiles>O=C(c1cc2ccccc2oc1=O)N1CCCCC1</smiles><smiles>CCOC(=O)c1cc2ccc(O)c(-c3cccc([N+](=O)[O-])c3)c2oc1=O</smiles><smiles>O=C(NCCN1CCCCC1)c1cc2ccccc2oc1=O</smiles>

13 LSPN272<smiles>CO/N=C1\CN(c2nc3c(cc2F)c(=O)c(C(=O)O)cn3C2CC2)CC1CN</smiles>
14 Gemifloxacin<smiles>COc1c(N2CC3NCCC[C@@H]3C2)c(F)cc2c(=O)c(C(=O)O)cn(C3CC3)c12</smiles>
15 Moxifloxacin<smiles>CC1COc2c(N3CCN(C)CC3)c(F)cc3c(=O)c(C(=O)O)cn1c23</smiles><smiles>CCCSc1ccc2[nH]c(NC(=O)OC)nc2c1</smiles><smiles>NC(=O)CI</smiles><smiles>O=C([O-])c1cccnc1C(=O)[O-]</smiles>

19 Quinolinate<smiles>NC(=O)C1=CN([C@@H]2O[C@H](COP(=O)(O)OP(=O)(O)OC[C@H]3O[C@@H](n4cnc5c(N)ncnc54)[C@H](O)C3O)[C@@H](O)[C@H]2O)C=CC1</smiles>

Figure 4. Structure of compounds screened as inhibitors to TcPEPCK. 
obtained percentage of $T c$ PEPCK inhibition is shown in the graphic in Figure 5.

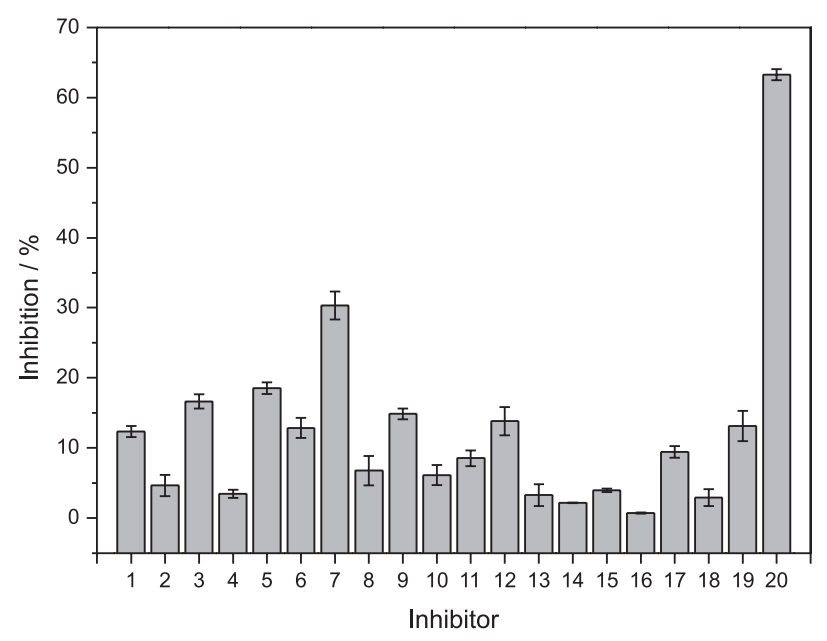

Figure 5. Inhibition values $(n=2)$ of the 20 small molecules screened at $150 \mu \mathrm{mol} \mathrm{L}-1$ OAA and $50 \mu \mathrm{mol} \mathrm{L}{ }^{-1}$ of inhibitors.

The values of inhibition obtained at $50 \mu \mathrm{mol} \mathrm{L}^{-1}$ were low $(<30 \%)$ except for NADH. Then, the seven compounds with higher inhibition percentage $(\mathbf{1}, \mathbf{3}, \mathbf{5}, \mathbf{7}, \mathbf{9}, 19$ and 20) were assayed at $450 \mu \mathrm{mol} \mathrm{L}^{-1}$. Inhibitions increased by up to $10 \%$, except for 19 that increased almost 4 times. This high increase by the quinolate is probably due to chelation of manganese at high concentration. The low inhibition values are in agreement for molecular fragments $(<300 \mathrm{Da})$, as described in the literature. ${ }^{49}$ The screened series was composed of NADH and 19 small molecules, with five of them below $400 \mathrm{Da}$ and fourteen below $300 \mathrm{Da}$.

The low binding affinities $\left(0.1-10 \mathrm{mmol} \mathrm{L}^{-1}\right)$ of a small molecule with a target enzyme is outside the detection range of most routine bioassays and explains why high-concentrations (> $100 \mu \mathrm{mol} \mathrm{L-1}$ ) are used. ${ }^{50}$ The LC-MS/MS method for TcPEPCK screening assay, herein disclosed, was capable to identify very low inhibition values (see compound 16) demonstrating to be a powerful tool for screening. Also, a very small amount of enzyme was used for each sample in contrast with traditional bioassays that require significant quantities of pure and soluble protein. ${ }^{49}$

Finally, we should call the attention to the percentage

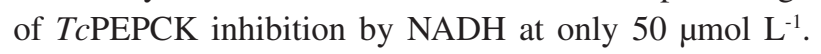
As discussed, classically PEPCK activity and inhibition are monitored by coupled assays using NADH-dependent enzymes with $\mathrm{NADH}$ at $\mathrm{mmol} \mathrm{L}^{-1}$ scale. This enhances the importance of the herein developed assay.

\section{Conclusions}

The enzymatic activity was determined by direct quantification of the produced PEP, minimizing the problems of coupled assays. Moreover, the direct quantification of the enzymatic product by LC-MS/MS facilitates the enzyme purification process. The method was applied for screening small molecules and was able to identify low inhibition values. In addition, NADH-dependent enzymes proved to be impractical for coupled assays with $T c$ PEPCK. Thus, in conclusion, the method herein described might be of value for PEPCKs from other sources.

\section{Supplementary Information}

The synthesis of three coumarins derivatives, method qualification data and screening of ligands are available free of charge at http://jbcs.sbq.org.br as PDF file.

\section{Acknowledgments}

This work was supported by São Paulo Research Foundation (FAPESP) (research grants 2013/01710-1 and 2014/50249-8), GSK and Agency for the Improvement of Higher Education Personnel (CAPES) (finance code 001). Grant No. 308187/2014-8 from the National Council for Scientific and Technological Development (CNPq) is also acknowledged.

\section{References}

1. Villarreal, J. M.; Bueno, C.; Arenas, F.; Jabalquinto, A. M.; Gonzalez-Nilo, F. D.; Encinas, M. V.; Cardemil, E.; Int. J. Biochem. Cell Biol. 2006, 38, 576.

2. Matte, A.; Tari, L. W.; Goldie, H.; Delbaere, L. T. J.; J. Biol. Chem. 1997, 272, 8105.

3. Trapani, S.; Linss, J.; Goldenberg, S.; Fischer, H.; Craievich, A. F.; Oliva, G.; J. Mol. Biol. 2001, 313, 1059.

4. Carlson, G. M.; Holyoak, T.; J. Biol. Chem. 2009, 284, 27037.

5. Cazzulo, J. J.; Decazzulo, B. M. F.; Engel, J. C.; Cannata, J. J. B.; Mol. Biochem. Parasitol. 1985, 16, 329.

6. Alves-Ferreira, M.; Guimaraes, A. C. R.; Capriles, P. V. S. Z.; Dardenne, L. E.; Degrave, W. M.; Mem. Inst. Oswaldo Cruz 2009, 104, 1100.

7. Urbina, J. A.; Parasitol. Today 1994, 10, 107.

8. Cazzulo, J. J.; J. Bioenerg. Biomembr. 1994, 26, 157.

9. Urbina, J. A.; Osorno, C. E.; Rojas, A.; Arch. Biochem. Biophys. 1990, 282, 91 .

10. Linss, J.; Goldenberg, S.; Urbina, J. A.; Amzel, L. M.; Gene 1993, 136, 69.

11. Utter, M. F.; Kurahashi, K.; J. Am. Chem. Soc. 1953, 75, 758.

12. Utter, M. F.; Kurahashi, K.; J. Biol. Chem. 1954, 207, 821.

13. Bandurski, R. S.; Lipmann, F.; J. Biol. Chem. 1956, $219,741$. 
14. Lane, M. D.; Chang, H. C.; Miller, R. S.; Methods Enzymol. 1969, 13, 270.

15. Berndt, J.; Ulbrich, O.; Anal. Biochem. 1970, 34, 282.

16. Latorre-Muro, P.; Baeza, J.; Armstrong, E. A.; Hurtado-Guerrero, R.; Corzana, F.; Wu, L. E.; Sinclair, D. A.; Lopez-Buesa, P.; Carrodeguas, J. A.; Denu, J. M.; Mol. Cell 2018, 71, 718.

17. Reyes-Ramos, C. A.; Peregrino-Uriarte, A. B.; Cota-Ruiz, K.; Valenzuela-Soto, E. M.; Leyva-Carrillo, L.; Yepiz-Plascencia, G.; Comp. Biochem. Physiol., Part B: Biochem. Mol. Biol. 2018, 226,1 .

18. Famiani, F.; Paoletti, A.; Proietti, P.; Battistelli, A.; Moscatello, S.; Cruz-Castillo, J. G.; J. Hortic. Sci. Biotechnol. 2018, 93, 456.

19. Famiani, F.; Baldicchi, A.; Casulli, V.; Di Vaio, C.; Cruz-Castillo, J. G.; Walker, R. P.; Acta Physiol. Plant 2017, 39, 260.

20. Ramnath, D. A. K.; Dkhar, B.; Tandon, V.; Das, B.; Parasitology 2017, 144, 1264.

21. Liu, R.; Wang, Y.; Qin, G.; Tian, S.; Postharvest Biol. Technol. 2016, 117, 57.

22. Dutta, A. K.; Ramnath; Tandon, V.; Das, B.; Parasitology 2016, 143, 300.

23. Koteyeva, N. K.; Voznesenskaya, E. V.; Edwards, G. E.; Plant. Sci. 2015, 235, 70.

24. Krebs, A.; Bridger, W. A.; Can. J. Biochem. 1976, 54, 22.

25. Wright, J. A.; Sanwal, B. D.; J. Biol. Chem. 1969, 244, 1838.

26. Kruger, N. J.; Phytochemistry 1995, 38, 1065.

27. Bisswanger, H.; Perspect. Sci. 2014, 1, 41.

28. Duff, D. A.; Snell, K.; Biochem. J. 1982, 206, 147.

29. Aguilar, Z.; Urbina, J. A.; Mol. Biochem. Parasitol. 1986, 21, 103.

30. Urbina, J. A.; Arch. Biochem. Biophys. 1987, 258, 186.

31. Jurado, L. A.; Machin, I.; Urbina, J. A.; Biochim. Biophys. Acta 1996, 1292, 188.

32. Cymeryng, C.; Cazzulo, J. J.; Cannata, J. J. B.; Mol. Biochem. Parasitol. 1995, 73, 91.
33. Vieira, L. C. C.; Paixão, M. W.; Corrêa, A. G.; Tetrahedron Lett. 2012, 53, 2715.

34. Lins, S. J.; Fragoso, S. P.; Goldenberg, S.; Mem. Inst. Oswaldo Cruz 1998, 93, 159.

35. Laemmli, U. K.; Nature 1970, 227, 680.

36. Bradford, M. M.; Anal. Biochem. 1976, 72, 248.

37. Cassiano, N. M.; Barreiro, J. C.; Martins, L. R. R.; Oliveira, R. V.; Cass, Q. B.; Quim. Nova 2009, 32, 1021.

38. GraphPad Prism, version 5.00; Intuitive Software for Science, San Diego, USA, 2007.

39. Godfrey, R. In Guide to Achieving Reliable Quantitative LC-MS Measurements, $1^{\text {st }}$ ed.; RSC Analytical Methods Committee: UK, 2013, p. 2.

40. Hatch, M. D.; Anal. Biochem. 1973, 52, 280.

41. Rathore, R.; Pribil, P.; Corr, J. J.; Seibel, W. L.; Evdokimov, A.; Greis, K. D.; J. Biomol. Screening 2010, 15, 1001.

42. Greis, K. D.; Mass Spectrom. Rev. 2007, 26, 324.

43. de Boer, A. R.; Lingeman, H.; Niessen, W. M. A.; Irth, H.; TrAC, Trends Anal. Chem. 2007, 26, 867.

44. Ratia, K.; Mehboob, S.; Lee, H.; Methods Mol. Biol. 2014, 1140, 291.

45. Delbaere, L. T.; Sudom, A. M.; Prasad, L.; Leduc, Y.; Goldie, H.; Biochim. Biophys. Acta 2004, 1697, 271.

46. Hunt, M.; Kohler, P.; Biochim. Biophys. Acta 1995, 1249, 15.

47. Salvarrey, M. S.; Cannata, J. J.; Cazzulo, J. J.; Biochem. J. 1989, 260, 221.

48. Foley, L. H.; Wang, P.; Dunten, P.; Ramsey, G.; Gubler, M. L.; Wertheimer, S. J.; Bioorg. Med. Chem. Lett. 2003, 13, 3871.

49. Ciulli, A.; Abell, C.; Curr. Opin. Biotechnol. 2007, 18, 489.

50. Scott, D. E.; Coyne, A. G.; Hudson, S. A.; Abell, C.; Biochemistry 2012, 51, 4990.

Submitted: January 31, 2019

Published online: May 3, 2019 